\title{
Market Discipline in Commercial Banking: Evidence from the Market for Bank Equity
}

\section{Ayesha Afzal ${ }^{*}$ and Nawazish Mirza**}

\begin{abstract}
This study presents empirical evidence of market discipline, using a panel dataset of listed banks on the Karachi Stock Exchange. We construct multiple riskbased measures from the stock prices between 2004 and 2009 to determine whether an increase in the risk profile results in an increase in compensation for depositors and other creditors. The risk variables used include market risk, value at risk, size and value premium, default likelihood indicator, price relatives, and a control variable representing gross domestic product growth. We find a significant relationship between our risk factors and cost of deposits, indicating that banks align deposit compensation with their risk perception. However, we cannot find a link between the market perception of risk and deposit switching. These findings have important implications for policymakers as market discipline could complement the state's regulatory role and lower the cost of supervision. Our estimations of value at risk and the default likelihood indicator using stochastic simulations is a methodological contribution that could be used for effective risk management practices.
\end{abstract}

Keywords: Market Discipline, Karachi Stock Exchange, Value at Risk, Default Likelihood Indicator.

JEL Classification: G20, G21.

\section{Introduction}

Financial markets facilitate capital allocation (and reallocation) from surplus to deficit units by direct financing, and thus contribute substantially to economic growth. Market-based financing is preferred when there are fewer market frictions emanating from various factors including (but not limited to) informational asymmetries, high flotation costs, extreme volatility, speculative behavior, and agency problems. Not

\footnotetext{
${ }^{*}$ Assistant Professor, Lahore School of Economics.

** Associate Professor, Lahore School of Economics. The authors would like to thank Mawal Sara Saeed for her assistance in collecting data.
} 
surprisingly-given their weak economic systems and inefficient regulatory controls-these inefficiencies are recurrent in almost all emerging economies. Therefore, in many developing countries, indirect financing or financing through a financial intermediary is common as banks, given their expertise, are expected to minimize transaction costs (search and monitoring), adverse selection, and moral hazard problems.

The main disadvantage of indirect financing is that financial intermediaries tend to take excessive risks, which, in an extreme situation, may lead to the systemic failure of the financial system. Commercial banks' probability of failure warrants a prudent supervisory and governance role on the part of the central bank. The financial sector's vulnerability to various risks-credit, market, liquidity, operational, offbalance sheet risks, and others-is critical both for the economy and related stakeholders (depositors, creditors, shareholders, and the government). Systemic risk can have a devastating impact on the financial system, as is evident in almost all banking crises. To safeguard the interests of all related participants, the financial sector is strongly regulated in all economies. This involves monitoring banks' risk activities and ensuring an adequate risk absorption capacity through the functioning of regulatory and monetary authorities who employ various instruments of control, such as capital adequacy, statutory liquidity reserve requirements, and minimum paid-up capital.

Despite the importance of indirect financing, we cannot undermine the need to develop a strong stock market, not only to facilitate the emergence and growth of new firms, but also because they play a disciplinary role. The stock price is the discounted contingent claim on a firm's future prospects. Mathematically, price $P_{(t+1)}$ is a function of discounted cash flows, given the information set $\Phi$ available at time $t$.

$$
P_{t+1}=\sum_{i=1}^{\infty} \frac{C F_{i} \mid \varphi_{t}}{(1+r)^{i}}
$$

The stock price formation process reflects investors' perceptions of the future of a firm by evaluating its manager's current actions. If market participants anticipate managerial efficiency, they will place a higher value on the firm; if not, they will penalize the firm for its inefficiencies by requiring higher compensation. 
To subordinate the historic onus of state supervision of the financial sector, Pillar III of the Basel Accord II (2001) introduced the concept of market discipline to promote the disciplinary role of private agents: depositors, bondholders, and shareholders. To ensure transparency, investors evaluate bank conditions, and banks make substantial disclosures of risk-related information in their financial statements. Based on this disclosure, stakeholders are expected to evaluate a bank's risk level and align their preferences accordingly. In case of an increase in the risk level, they should either demand a higher risk premium or else diversify their portfolios to manage their risk appetite. Therefore, market discipline comprises two mutually independent aspects. The first aspect is stakeholders' ability to monitor and identify any changes in a bank's fundamentals, and the second is stakeholders' power to influence the actions of the bank's management by manipulating their required rate of returns. The empirical literature suggests three possible sources through which to test for the presence of market discipline: (i) markets for uninsured liabilities, (ii) markets for subordinate debt, and (iii) markets for bank equity. The focus of this study is on markets for bank equity; we discuss the market discipline imposed by uninsured liabilities in a subsequent study.

In Pakistan, capital market reforms were introduced to enhance the efficiency and transparency of capital markets to provide a meaningful medium through which to raise long-term capital. Surprisingly, despite these reforms-aimed at eliminating market imperfections by reducing information asymmetries, moral hazard, and speculative trading - the last decade witnessed a limited number of initial public offerings or seasoned offerings. ${ }^{1}$ Likewise, bond markets have remained underdeveloped with very few publicly placed term finance certificates leaving banking and nonbanking financial institutions as a major source of short- and long-term capital. Yet, despite the tremendous increase in market activity over the last decade with notable trading volumes and upsurges in index value, the failure of stock markets as a platform from which to raise capital can be partly attributed to the high volatility and speculative component ${ }^{2}$ that hinders businesses from raising capital through a turbulent source. Table 1 summarizes the statistics of the Karachi Stock Exchange (KSE) for the last five years. The

\footnotetext{
${ }^{1}$ The initial public offerings or seasoned offerings that took place between 2001 and 2010 were either a move toward increasing outside shareholdings in public sector firms, or to enhance the regulatory capital base (banks) under the Basel II framework.

${ }^{2}$ For more on speculative bubbles in the Karachi Stock Exchange, see Mirza and Afzal (2009).
} 
number of new listings for both debt and equity instruments per year clearly represents the lack of market activity in terms of raising capital.

Given this sort of market activity, we cannot expect a strong form of market discipline. However, another unique feature of the KSE is the high turnover of banking stocks-unlike in most other developed and emerging markets where financial stocks are subject to nonsynchronous trading (Lieven et al., 2007) and firm-specific variables dominate the pricing of banking stocks ${ }^{3}$-and active trading. If complemented by bank fundamentals, they may help enforce market discipline. Table 2 presents the average (five years) turnover for various KSE sectors. The banking sector is the most active, contributing approximately 46 percent of the average shares traded in the last five years. Thus, it is interesting to observe whether capital markets impose some sort of market discipline on the volume-leading sector.

\footnotetext{
${ }^{3}$ Mirza and Alexandre (2009) provide evidence that asset quality specific to commercial banks measured as the ratio of nonperforming loans to gross loans is a systematic risk factor that is priced in European financial stocks.
} 
Table 1: The Karachi Stock Exchange at a Glance

\begin{tabular}{|c|c|c|c|c|c|}
\hline & 2006 & 2007 & 2008 & 2009 & 2010 \\
\hline \multicolumn{6}{|c|}{ Equities } \\
\hline Listed companies & 651 & 654 & 653 & 651 & 644 \\
\hline $\begin{array}{l}\text { Listed capital } \\
\text { (PKR million) }\end{array}$ & $515,029.54$ & $671,269.47$ & $750,477.55$ & $814,478.74$ & $919,161.26$ \\
\hline $\begin{array}{l}\text { Market } \\
\text { capitalization } \\
\text { (PKR million) }\end{array}$ & $2,766,583.84$ & $4,329,909.79$ & $1,858,698.90$ & $2,705,879.83$ & $3,268,948.59$ \\
\hline $\begin{array}{l}\text { New companies } \\
\text { listed }\end{array}$ & 9 & 14 & 10 & 4 & 6 \\
\hline $\begin{array}{l}\text { Listed capital } \\
\text { (PKR million) }\end{array}$ & $14,789.76$ & $57,239.93$ & $15,312.12$ & $8,755.74$ & $33,438.45$ \\
\hline \multicolumn{6}{|c|}{ Debt Instruments } \\
\hline $\begin{array}{l}\text { New debt } \\
\text { instruments listed }\end{array}$ & 3 & 3 & 7 & 1 & 4 \\
\hline $\begin{array}{l}\text { Amount listed } \\
\text { (PKR million) }\end{array}$ & $3,400.00$ & $6,500.00$ & $25,256.97$ & $3,000.00$ & $5,650.18$ \\
\hline \multicolumn{6}{|c|}{ KSE-100 Index } \\
\hline High & 12273.77 & 14814.85 & 15676.34 & 9845.74 & 12031.46 \\
\hline Low & 8766.98 & 10066.32 & 5865.01 & 4815.34 & 9229.6 \\
\hline Year's end & 10040.5 & 14075.83 & 5865.01 & 9386.92 & 12022.46 \\
\hline \multicolumn{6}{|c|}{ KSE-30 Index } \\
\hline High & 14020.56 & 18083.15 & 18996.33 & 10508.35 & 11588.97 \\
\hline Low & 12248.93 & 12550.26 & 5485.33 & 4428.1 & 9104.25 \\
\hline Year's end & 12521.54 & 16717.1 & 5485.33 & 9849.92 & 11588.24 \\
\hline \multicolumn{6}{|c|}{ Turnover of Shares } \\
\hline $\begin{array}{l}\text { Total shares (PKR } \\
\text { million) }\end{array}$ & $63,046.52$ & $65,956.89$ & $36,527.96$ & $44,446.88$ & $33,529.72$ \\
\hline $\begin{array}{l}\text { Average daily } \\
\text { turnover (million) }\end{array}$ & 260.69 & 268.23 & 146.55 & 179.88 & 132.64 \\
\hline
\end{tabular}

Source: Karachi Stock Exchange.

\section{Table 2: Turnover Contribution by Sector (Five-Year Average)}

\begin{tabular}{lc}
\hline Sector & Turnover Contribution (\%) \\
\hline Banks & 45.99 \\
Chemicals & 24.88 \\
Oil and gas & 4.70 \\
Equity investment instruments & 3.05 \\
Construction and materials & 2.42 \\
Others (29 sectors) & 18.96 \\
\hline Total & $\mathbf{1 0 0 . 0 0}$ \\
\hline
\end{tabular}

Source: Karachi Stock Exchange. 
In Pakistan, the Pillar III disclosure requirements for market discipline were completed by December 2005; all financial institutions in the country now follow a standard format for the dissemination of financial statements (State Bank of Pakistan, BSD Circular No. 3, 31 March 2005). The implementation of Basel II, Pillars I, II, and III was to be completed in two phases with the adoption of standardized risk management approaches by January 2008 and an internal rating-based approach by January 2010 (State Bank of Pakistan, BSD Circular No. 1, 1 January 2008). Surprisingly, despite these financial reforms and the adoption of Basel II, there is no empirical research to establish the presence of market discipline in Pakistan. This study is therefore primary research analyzing the dynamics of market discipline in a post-reform period.

Using an unbalanced panel of listed banks over a period of six years, we find some evidence of market discipline in Pakistan's commercial banking sector. We find support for the notion that stock prices reveal important risk-related information and that banks offer compensation when they are perceived as risky. Since banks provide a premium for high risk, we find no evidence that an increase in risk might result in deposit switching. These findings provide some preliminary insight into the dynamics of market discipline in Pakistan. We also contribute to the field by suggesting sophisticated quantitative procedures for risk estimation that financial institutions could use to adopt an internal rating-based approach. The rest of the article is organized as follows. Section 2 provides a brief literature review, Section 3 builds on the methodology used, Section 4 presents our empirical findings, and Section 5 concludes the study.

\section{Literature Review}

Shimizu (2009) analyzes the discipline imposed by depositors, using stock market information. He argues that informed participants in the stock market base their investment decisions on analytical information that is not disclosed in banks' financial statements. This is not directly observable by the uninformed depositors so they rely on stock market information to assess a bank's financial health. He uses a sample of Japanese banks to study the determinants of variations in the deposit base: bank-specific variables (profitability, capital adequacy, etc.), the contagion variable of growth in stock prices, and some important macro-variables. He finds evidence of a significant relationship between a fall in price and withdrawal of deposits, concluding that a fall in share prices signals a higher probability of bank failure and will result in a higher withdrawal rate. 
Gropp, Vesala, and Vulpes (2006) study the impact of stock and bond market information on bank fragility for a sample of 103 US banks between 1991 and 2003. The KMV distance to default is the lead indicator for equity markets while spread on subordinated debt is the proxy for debt markets. Bank fragility is measured as a downgrade to a speculative rating of $\mathrm{C}$ or below by FITCH ratings. The results show that both distance to default and spread on subordinated debts are able to predict bank fragility, with distance to default predicting a crisis at least 18 months in advance and spread predicting one only 12 months in advance. They conclude that equity market data provides participants with more valuable information to forecast and differentiate between good banks and weak banks.

Bremer and Pettway (2002) address the issue of market discipline from a different point of view. They study the impact of a ratings downgrade on share prices and managers' reactions to this decline. The credit ratings reflect a bank's capacity to service its obligations and a downgrade signals a reduction in creditworthiness. They use various event windows to estimate the reaction of stock prices to a downgrade announcement. The sample constitutes 73 announcements for 49 Japanese banks spanning the period between 1986 and 1998. The results provide weak evidence for market discipline, showing the significant sensitivity of stock prices to credit ratings and that market participants are able to differentiate between strong and weak banks and penalize the former. However, the management's reaction to this penalty is nonexistent. This lack of managerial response to market discipline is consistent with the results of Anderson and Campbell (2000), which relate managerial inefficiencies in Japanese banks to corporate governance. Bremer and Pettway (2002) identify the lack of supervision in the Japanese financial system and conclude that Basel disclosure requirements are not sufficient to impose rigorous discipline.

Bongini, Laeven, and Majnoni (2002) compare the extent of information that can be extracted from a set of variables to indicate bank fragility. Their sample comprises East Asian banks between 1996 and 1998, and the variables' sources include balance sheet data (CAMEL ratings), stock market prices, and credit ratings. Their research is based on both ex post and forecasted ex ante estimates. The results show unique patterns of information from the three sets of variables. The ex post balance sheet variables provide significant information discriminating between banks of varying financial health. The stock price and rating variables do not provide any information that can be used by investors to impose market discipline. The ex ante estimates favor the equity market 
variables followed by balance sheet sources, while the rating variable remains insignificant. They conclude that multiple sources of public information are likely to provide variable signals, and that investors in less developed financial systems should rely on multiple indicators of bank fragility to enforce market discipline.

\section{Data and Methodology}

\subsection{Sample Criteria}

This study employs panel data on various equity market variables to examine empirically whether stock prices reveal any relevant information that can be used to impose market discipline in Pakistan's commercial banking sector. The sample has been selected based on following criteria:

1. The sample period spans the post-financial reform period from 2004 to 2009, and the period during which commercial banks were adopting the disclosure requirements proposed under Pillar III of the Basel Accord.

2. Only publicly listed banks with data available on balance sheets, income statements, and stock prices are included.

3. The survivorship bias is addressed by excluding merged or delisted banks.

Based on these criteria, our final sample consists of an unbalanced panel. The number of banks in each sample year is as follows.

\section{Sample Distribution 2004-09}

\begin{tabular}{lcccccc}
\hline Year & 2009 & 2008 & 2007 & 2006 & 2005 & 2004 \\
\hline No. of banks & 25 & 25 & 25 & 24 & 21 & 21 \\
\hline
\end{tabular}

The information on bank fundamental variables on an annual basis has been extracted from the yearly financial reports of the respective banks, while capital market data has been extracted from the KSE website.

\subsection{Estimating Market Discipline}

As mentioned earlier, the literature on market discipline identifies three types of markets that can be examined to ascertain market 
discipline. In Pakistan's case, only two of these three are relevant: (i) the market for uninsured liabilities, and (ii) the market for bank equity. This is mainly because of the significant presence of deposits and shareholders' equity in banks' capital structure. Subordinated debt is not an important source of financing in Pakistan's commercial banks, given the negligible existence of debt markets.

\subsubsection{Dependent Variables}

Financial economic theory presents two main rationales in the riskand-return relationship. First, risk and return should be correlated, and an increase in risk level should increase the required rate of return. If markets exhibit some discipline, depositors should be able to differentiate between high- and low-risk banks, and penalize excessive risk-taking by augmenting the cost of deposits/funds (requiring a high return). The cost of funds is estimated as, $c_{i t}=\left(\frac{I E_{i t}}{\operatorname{IntLiab_{it}}}\right)$, where $c_{i t}$ represents the percentage cost of capital, $I E_{i t}$ represents the interest paid to depositors, and IntLiab $b_{i t}$ reflects all interest-bearing liabilities for bank $i$ at time $t$.

The second aspect relates to participants' risk tolerance. Every investor has their own utility function of risk and will not choose assets that are beyond their risk limits even if such assets offer a high risk premium. In the presence of market discipline, this phenomenon for banks generally results in deposit switching from high- to low-risk banks. A switch in deposits is estimated as a year-on-year change on deposits. Mathematically, this variable is represented as $\Delta D_{t}=\lambda_{i t}=\frac{\Delta \mathrm{D}_{\mathrm{it}}}{D_{i t-1}}$, with $\lambda_{i t}$ indicating a switch in depositors, $\Delta D_{i t}$ the deposits of bank $i$ in year $t$, and $D_{i t-1}$ as the deposits of bank $i$ in year $t-1$.

\subsubsection{Independent Variables-Market for Bank Equity}

The primary advantage of stock market information is that, unlike accounting variables-which reflect past transactions-stock prices are forward looking. Moreover, informed traders, fund managers, and financial analysts in these markets have greater information and superior capacity for analyzing this information. Therefore, the discipline of imposing a higher cost of funds or penalizing weak banks by switching deposits can be based on information extracted from stock prices. The fixed effect regression models are: 


$$
\begin{aligned}
& c_{i t}=\alpha_{i}+\beta_{1} \delta_{i t}+\beta_{2} V A R_{i t}+\beta_{3} D L I_{i t}+\beta_{4} B / M_{i t}+\beta_{5} \operatorname{Ln}\left(M V_{i t}\right)+\beta_{6} \frac{\Delta P_{t}}{P_{t-1}} \\
& +\beta_{6} \Delta g d p_{t}+\varepsilon_{i t} \ldots \ldots \\
& \frac{\Delta D_{i t}}{D_{i t-1}}=\alpha_{i}+\beta_{1} \delta_{i t}+\beta_{2} V A R_{i t}+\beta_{3} D L I_{i t}+\beta_{4} B / M_{i t}+\beta_{5} \operatorname{Ln}\left(M V_{i t}\right)+\beta_{6} \frac{\Delta P_{t}}{P_{t-1}} \\
& +\beta_{6} \Delta g d p_{t}+\varepsilon_{i t} \ldots \ldots
\end{aligned}
$$

Where $\delta_{i t}$ is systematic risk, $\mathrm{VAR}_{\mathrm{it}}$ is the value at risk, $\mathrm{DLI}_{\mathrm{it}}$ is the default likelihood indicator, $\mathrm{B} / \mathrm{M}_{\mathrm{it}}$ is the book-to-market value, $\mathrm{MV}_{\mathrm{it}}$ is the market value (size), and $\Delta \mathrm{P}_{\mathrm{t}} / \mathrm{P}_{\mathrm{t}-1}$ is the stock return (price relatives).

Systematic Risk $\delta_{i t}$

A firm's systematic risk reflects its sensitivity to the stock market as a whole. Firms with higher systematic risk will experience shocks to equity, and a negative shock is expected to erode the buffer against losses since, in the financial sector, equity acts more as a source of risk absorption capacity rather than a means of financing. Hamada (1969) and Breen and Lerner (1973) provide theoretical analyses that suggest that differences in the "beta" of each firm should be related to differences in their risk and financial management activities. Therefore, one would expect the estimated beta to reflect each firm's risk-and-return characteristics. Since beta is not directly observable, we estimate it using the Sharpe (1964) single-index model. The daily returns of each year are regressed on the index returns to obtain an estimate of nondiversifiable risk. This takes the form $R_{i t}=\alpha_{i}+\delta_{i} R_{m t}+\varepsilon_{t}$, with $R_{i t}$ as the return on an individual stock, and $R_{m t}$ as the return on the market index. To account for possible autocorrelation and heteroscedasticity of unknown form, beta is estimated using the generalized method of moments approach since it does not require the distribution of the disturbance term. The market return is represented using the return on the KSE-100 index as a proxy, but we feel that KSE-100 might not be representative, so we also create a synthetic value-weighted bank index (based on all listed banking stocks and weights rebalanced every six months) to provide a robust estimate of systematic risk. Depositors would perceive a high coefficient on systematic risk as negative, and this would result in the increased cost of deposits and a high possibility of switching. 
Value at Risk (VAR)

In order to estimate total risk, we use a more sophisticated tool, VAR, to analyze its impact on the cost of funds. VAR refers to the maximum loss expected in a given investment horizon. Ex post volatility ignores the direction of an investment movement. Observed volatility might be high if historical prices undergo an abnormal increase, which is not an indication of distress. VAR is considered a more appropriate measure of risk because-unlike standard deviation or volatility-it only considers the left tail of returns. To estimate VAR, we deploy Monte Carlo simulation to predict ex ante stock prices using a geometric Brownian motion (GBM) approach, and calculate the returns to estimate the worst-case loss with a 99 percent confidence interval. This process is repeated for each bank in the sample for every year, and the estimated VAR is used in our panel regression. The simulation process for price estimation is as follows.

Assuming price $P$ for bank $i$, and following the GBM approach, this stochastic process can be expressed as:

$$
d P=\alpha P d t+\sigma P d z
$$

$d z$ is the Wiener increment of $\varepsilon d t^{0.5}, \varepsilon$ follows a normal distribution, $\alpha$ represents drift (or price differential), and $\sigma$ represents volatility in price $P$. To estimate the growth in prices, we use total investment returns $\mu$ as a function of capital gains $\alpha$ and dividend yield $\delta$. Mathematically, this is written as:

$$
\mu=\alpha+\delta
$$

$\mu$ is also the risk-adjusted discount rate for price $P$. The stochastic expression is written as:

$$
d P=(\mu-\delta) P d t+\sigma P d z \quad \ldots \ldots \ldots \ldots \ldots
$$

Assuming a risk-neutral world, we can replace $\mu$ with risk-free rate $r$ and the risk-neutral price formation process will be:

$$
d P=(r-\delta) P d t+\sigma P d z \quad \ldots \ldots \ldots \ldots \ldots
$$

Equations 3 and 4 represent the risk-adjusted and risk-neutral versions of the price formation process, respectively. Applying a log normal transformation and combining with Ito's lemma, we derive the 
following simulation equations for risk-adjusted (Equation 5) and riskneutral equations (Equation 6).

$$
\begin{aligned}
& P_{t}=P \exp \left[\left(\alpha-0.5 \sigma^{2}\right) \Delta t+\sigma N(0,1) \sqrt{\Delta t}\right] \quad . \\
& P_{t}=P \exp \left[\left(r-\delta-0.5 \sigma^{2}\right) \Delta t+\sigma N(0,1) \sqrt{\Delta t}\right] .
\end{aligned}
$$

Simulating Equations 5 and 6 gives us stock price $P_{t}$ at any future interval $t$ with normal distribution $N \sim(0,1)$. Once the expected prices have been estimated, we back-test for significance; the $t$ statistics in mean difference suggest that the risk-adjusted equation provides a better estimate of ex ante prices. For every bank in the sample, we simulate future prices using a daily frequency. Once $P_{t}$ has been estimated, we estimate daily logarithmic returns to calculate the daily VAR at a 99 percent significance level. This daily VAR is then annualized using continuous compounding for yearly estimation in panel regressions.

\section{Default Likelihood Indicator (DLI)}

Traditional measures of default risk take into account the volatility of the book value of assets. However, in the extreme case of default, only the market value (MV) of assets matters. The latter (and related volatility) per se is not evident because while the MV of equity is observable, not all liabilities are marked to market. Merton (1974) proposed an asset value model to extract credit information embedded in equity markets using the Black and Scholes (1973) option pricing framework.

The asset value model treats the firm's equity as a call option (European) on the firm's assets with a maturity period equal to the maturity of its debt and strike price equal to the amount paid to the creditors. The firm will be distant from default as long as the MV of its assets exceeds the amount of liabilities to be repaid. In the option pricing framework, the MV of a bank's assets follow a GBM of the form:

$$
d V_{A}=\mu V_{A} d t+\sigma_{A} V_{A} d W
$$

$V_{A}$ is the bank's asset value, with drift $\mu$ and volatility $\sigma_{A}$ in a standard Wiener process $W$. The equity of the bank $V_{E}$ with liabilities $X$ of maturity $T$, a risk-free rate of $r$, and a cumulative density function $N$ with a normal standard distribution, can be modeled as 


$$
\begin{aligned}
& V_{E}=V_{A} N\left(d_{1}\right)-X e^{-r T} N\left(d_{2}\right) \\
& \text { with } d_{1}=\frac{\ln \left(V_{A} / X\right)+\left(r+1 / 2 \sigma_{A}^{2}\right) T}{\sigma_{A} \sqrt{T}} \text {, and } d_{2}=d_{1}-\sigma_{A} \sqrt{T}
\end{aligned}
$$

It is possible to estimate $V_{A}$ from the above equation if the value of $\sigma_{A}$ is known. To calculate $\sigma_{A}$, we use the iterative process proposed by Vassalou and Xing (2004). ${ }^{4}$ Initially, the past 12 months' daily prices for every bank are used to estimate the volatility of equity $\sigma_{E}$. This estimate is used as a proxy for $\sigma_{A}$ and daily $V_{A}$ is calculated given $V_{E}$. In the next step, the standard deviation of $V_{A}$ is estimated and used as $\sigma_{A}$ for the next iteration. This process is repeated till both estimates of $\sigma_{A}$ and $\sigma_{E}$ converge within 0.0001 . Once the converged value is obtained, we re-estimate $V_{A}$ for every bank and calculate drift $\mu$ as the $\log$ of $V_{A}$. Xi refers to liabilities maturing within $T$ (one year) and $r$ is the daily yield from one-year t-bills. Once all these variables are in place, the DLI (distance to default) can be estimated as

$$
D L I_{i t}=1-N\left[\frac{\ln \left(V_{A i} / X i\right)+\left(r+1 / 2 \sigma_{A i}^{2}\right) T}{\sigma_{A i} \sqrt{T}}\right]
$$

The lower DLI would imply a low level of default risk; banks that are distant from default are expected to have a low cost of funds.

\section{Book-to-Market and Size (Market Cap)}

Fama and French (1992) proposed an extension of the CAPM by adding two more factors. They noted that two classes of stocks perform better than the market as a whole: (i) stocks with small market capitalization, and (ii) stocks with a high book value per share to price (MV) ratio. Since these stocks yield a higher return than the market, the authors explain the phenomenon through the existence of a size as well as value premium in addition to the market risk premium of systematic risk. High book-to-market value ratio stocks are termed "value stocks" while low book-to-market value ratio stocks are termed "growth stocks." The size factor measures the additional returns that investors receive for participating in stocks with comparatively small market capitalization. Stocks with a high book-to-market value and low market cap are considered to be risky, and depositors should demand higher interest rates as risk compensation.

\footnotetext{
${ }^{4}$ A similar iterative process is used by Moody's KMV to estimate the expected default frequency.
} 


\section{Stock Returns/Price Relatives}

A firm's equity represents shareholders' contingent claims on the firm's assets and future cash flows. Therefore, stock market prices are expected to reflect the value that investors would place on the firm's future prospects. The price formation process is also a strong reflection of the expectations of informed investors (including insider information) who have better skills with which to analyze the bank's fundamentals. Consequently, stocks are expected to be fairly priced and depositors are able to deduce valuable information about the bank's perceived financial position.

We estimate average intraday price relatives for bank equity, which are used as an explanatory variable for the cost of funds and deposit switching. Large price relatives indicate a proportional increase in prices representing investors' confidence about the bank's future; in the presence of market discipline, depositors should require a low rate of return. Similarly, banks with high price relatives are not expected to experience a high variation in deposits. Finally, we use gross domestic product (GDP) as a macroeconomic variable to control for factors that may cause broad movements in the availability of deposits to the banking system.

\section{Empirical Results}

The average descriptive statistics for dependent and independent variables are reported in Table 3. The cost of funds for the sample banks increase over the years with a minimum of 3.26 percent in 2005 and 6.83 percent in 2009, representing an overall increase in the cost of borrowing. Systematic risk, measured by the beta coefficient (both for the KSE-100 and bank-specific index), also increases, showing a rise in the risk perception of stock market participants. A similar pattern is observed for VAR and the DLI. The information extracted from stock price data reflects an overall increase in the risk perception, and the increase in the cost of funds is likely compensation for the incremental risk. 
Table 3: Average Descriptive Statistics for Dependent and Independent Variables

\begin{tabular}{lllllll}
\hline & $\mathbf{2 0 0 4}$ & $\mathbf{2 0 0 5}$ & $\mathbf{2 0 0 6}$ & $\mathbf{2 0 0 7}$ & $\mathbf{2 0 0 8}$ & $\mathbf{2 0 0 9}$ \\
\hline Cost of funds (\%) & 4.550 & 3.262 & 4.924 & 5.465 & 6.468 & 6.833 \\
Beta (bank index) & 0.912 & 0.871 & 0.903 & 0.815 & 1.239 & 1.513 \\
Beta (KSE-100) & 0.610 & 0.638 & 0.766 & 0.734 & 1.027 & 1.130 \\
VAR (\%) & 8.220 & 5.957 & 9.698 & 6.382 & 9.687 & 9.378 \\
DLI (\%) & 0.070 & 0.810 & 1.950 & 1.350 & 0.990 & 0.890 \\
B/M & 0.852 & 1.103 & 0.717 & 0.624 & 0.615 & 1.199 \\
$\Delta \mathrm{P}(\%)$ & 0.140 & 0.290 & 0.016 & 0.116 & -0.602 & -0.007 \\
\hline
\end{tabular}

$\mathrm{DLI}=$ default likelihood indicator, $\mathrm{KSE}=$ Karachi Stock Exchange, VAR $=$ value at risk. Source: Authors' calculations.

The fixed effect regression results for the cost of funds using the KSE-100 index are reported in Table 4. We find a highly significant negative coefficient on the size variable, suggesting that banks with a strong equity base are likely to face a lower cost of funds. This is expected because a strong capital base provides substantial risk absorption capacity against unforeseen losses.

Table 4: Regression Results Using KSE-100 Index

Dependent variable: Cost of deposits/borrowing

\begin{tabular}{lccccr}
\hline \multicolumn{1}{c}{ Variable } & Coefficient & Std. Error & t ratio & p value & Significance \\
\hline Beta (systematic risk) with & 0.0094 & 0.0055 & 1.7067 & 0.0914 & $*$ \\
KSE-100 & & & & & \\
VAR & 0.0685 & 0.0336 & 2.0349 & 0.0447 & $* *$ \\
Book-to-market (value) & 0.0096 & 0.0050 & 1.9097 & 0.0606 & $*$ \\
Size (MV of equity) & -0.0061 & 0.0023 & -2.6424 & 0.0097 & $* * *$ \\
DLI (KMV, Merton) & 0.0982 & 0.0477 & 2.0574 & 0.0426 & $*$ \\
Price & -0.0045 & 0.0045 & -0.9991 & 0.3204 & $*$ ** \\
Growth in GDP & -0.0763 & 0.0274 & -2.7874 & 0.0065 & \\
Constant & -0.0056 & 0.0062 & -0.8953 & 0.3730 & \\
\hline R-squared & 0.5613 & & & & \\
Adj. R-squared & 0.5280 & & & & \\
F statistic & 16.8181 & & & & \\
p value (F) & 0.0000 & & & & \\
\hline
\end{tabular}

DLI $=$ default likelihood indicator, GDP $=$ gross domestic product, KSE $=$ Karachi Stock Exchange, $\mathrm{MV}=$ market value, $\mathrm{VAR}=$ value at risk.

${ }^{* * *}$ represents significance at $99,{ }^{* *}$ at 95 , and $*$ at 90 percent.

Source: Authors' calculations. 
Both the DLI and VAR are significant and positive, demonstrating a direct relation between the two risk variables and the cost of funds; an increase in these variables is likely to impose a higher cost of borrowing. The control variable of GDP growth is negative, suggesting that an increase in economic activity would result in an increase in surplus units, enabling banks to mobilize deposits at a low cost. The book-to-market variable is moderately significant with a positive sign, suggesting a direct relation between value stocks and the cost of deposits. Value stocks are perceived as riskier, and banks with a high book-to-market ratio are expected to compensate their depositors with higher returns.

The variable for systematic risk yields some interesting results. When beta was estimated using the KSE-100 index, the variable was significant at 10 percent with a positive coefficient. However, the results in Table 5 suggest that, when beta is estimated using a more representative market index (in this case bank-specific), the variable is highly significant and positive, implying that an increase in market risk would be compensated for by higher returns to depositors and creditors. It is also interesting to note that, in the presence of more representative market risk, the two other risk measures-VAR and DLI-lose their explanatory power.

Table 5: Regression Results Using Bank-Specific Index

Dependent variable: Cost of deposits/borrowing

\begin{tabular}{lccccr}
\hline \multicolumn{1}{c}{ Variable } & Coefficient & Std. Error & t ratio & p value & Significance \\
\hline Beta (systematic risk) with & 0.14956 & 0.01834 & 8.1533 & 0.00000 & $* * *$ \\
bank index & & & & & $*$ \\
VAR & 0.00940 & 0.00550 & 1.7067 & 0.09140 & $*$ \\
Book-to-market (value) & 0.08907 & 0.04634 & 1.9220 & 0.05770 & $*$ \\
Size (MV of equity) & -0.06940 & 0.03440 & -2.0182 & 0.04660 & $*$ \\
DLI (KMV, Merton) & 0.08579 & 0.04383 & 1.9572 & 0.05699 & $*$ \\
Price & -0.00560 & 0.00620 & -0.8953 & 0.37300 & \\
Growth in GDP & -0.00830 & 0.00160 & -5.1309 & 0.00000 & \\
Constant & -0.00110 & 0.00250 & -0.4374 & 0.66280 & \\
\hline R-squared & 0.58440 & & & & \\
Adj. R-squared & 0.55270 & & & & \\
F statistic & 18.4785 & & & & \\
p value (F) & 0.00000 & & & & \\
\hline
\end{tabular}

DLI = default likelihood indicator, GDP = gross domestic product, $\mathrm{MV}=$ market value, $\mathrm{VAR}=$ value at risk .

*** represents significance at 99 , and * at 90 percent.

Source: Authors' calculations. 
This would mean that VAR and DLI also explain, in part, market risk, which is captured by beta if an appropriate stock market index is used. There is no change in size, and the GDP growth variable remains negative and highly significant. We find no evidence in support of incremental price changes. The overall model fit is satisfactory with an adjusted $\mathrm{R}^{2}$ of 52.8 percent when the KSE-100 index is used to estimate the proxy for market risk. This rises marginally to 55.2 percent when we employ our synthetic bank to estimate beta. The results support the presence of market discipline, albeit a moderate degree, as about 55 percent of the variation in cost of funds is explained by our market-based risk measures. The significance of these variables also suggests that stock market prices reveal important information that can be useful in assessing the risk profile of banking firms.

It is worthwhile to mention that the significance of the size factor could ultimately lead to moral hazard. Since banks with a strong equity base are likely to be big banks and assumed to have an adequate cushion to absorb losses, the "too big to fail" fallacy could result in additional risk-taking without compensating the stakeholders. These incremental risks could lead to a "black swan" event, resulting in a transition from "too big to fail" to "too big to save."

We attempt to study deposit-switching behavior using pricebased risk measures, but do not find substantial evidence to support it. The macroeconomic control variable of GDP growth and size based on the MV of equity was significant and negative, providing a rationale for the presence of strong equity. All other variables are insignificant and, therefore, the overall explanatory power of the results for deposit switching is low, with an adjusted $\mathrm{R}^{2}$ of 29.3 percent (Table 6). 


\section{Table 6: Regression Results for Deposit Switching}

Dependent variable: Deposit switching

\begin{tabular}{lrrrrr}
\hline \multicolumn{1}{c}{ Variable } & Coefficient & Std. Error & \multicolumn{1}{c}{ r ratio } & p value & Significance \\
\hline Beta (systematic risk) & 0.185645 & 0.6907970 & 0.2687 & 0.78875 & \\
with bank index & & & & & \\
VAR & 0.031006 & 0.3132000 & 0.1010 & 0.91980 & \\
Book-to-market (value) & 0.011600 & 0.0072000 & 1.6130 & 0.11010 & \\
Size (MV of equity) & -0.080760 & 0.0333293 & -2.4231 & 0.01741 & $* *$ \\
DLI (KMV, Merton) & 0.027200 & 0.1215000 & 0.2239 & 0.82360 & \\
Price & -0.043947 & 0.0903355 & -0.4865 & 0.62782 & \\
Growth in GDP & -0.078147 & 0.0273829 & -2.8539 & 0.00532 & $* * *$ \\
Constant & 0.027700 & 0.0471000 & 0.5883 & 0.55830 & \\
\hline R-squared & 0.343375 & & & & \\
Adj. R-squared & 0.293414 & & & & \\
F statistic & 6.872901 & & & & \\
p value (F) & 0.000000 & & & & \\
\hline
\end{tabular}

DLI = default likelihood indicator, GDP = gross domestic product, $\mathrm{MV}=$ market value, $\mathrm{VAR}=$ value at risk .

*** represents significance at 99 , and ${ }^{* *}$ at 95 percent.

Source: Authors' calculations.

There could be plausible reasons for the inadequacy of our results for deposit switching. One possible explanation is that, with an increase in the risk profile as perceived by the financial market, banks offer higher returns to satiate the risk appetite of depositors so that they and other creditors have no motivation to switch banks. To test this rationale, we augment our model for deposit switching with the cost of deposits. Table 7 presents the regression results attained when the cost of deposits is used as an explanatory variable for deposit switching along with our market-based variables.

Although the overall goodness of fit does not increase, the cost of deposits is highly significant and negative, suggesting that banks could retain their clients by compensating them for the incremental risks. ${ }^{5}$ However, we do not stress this hypothesis because it is a weaker explanation, and we strongly feel that deposit-switching behavior should be examined in greater depth beyond the notion of market discipline. ${ }^{6}$

\footnotetext{
${ }_{6}^{5}$ Afzal and Mirza (2010) present evidence that Pakistan's banking deposits are interest rate-sensitive.

${ }^{6}$ These results remain robust when we use quarterly and semi-annual data frequencies, and historical, variance-covariance, and mean-reverting approach for VAR and SMB and HML factors for size and value, respectively.
} 


\section{Table 7: Regression Results}

Dependent variable: Deposit switching

\begin{tabular}{lccccc}
\hline \multicolumn{1}{c}{ Variable } & Coefficient & Std. Error & t ratio & p value & Significance \\
\hline Cost of deposits & -0.0633 & 0.0192 & -3.2995 & 0.0014 & $* * *$ \\
Beta (systematic risk) with & 0.3640 & 0.3563 & 1.0220 & 0.3096 & \\
bank index & & & & & \\
VAR & 0.0817 & 0.0805 & 1.0150 & 0.3139 & \\
Book to market (value) & 0.0510 & 0.1468 & 0.3470 & 0.7297 & \\
Size (MV of equity) & -0.0961 & 0.0320 & -2.9990 & 0.0035 & $* * *$ \\
DLI (KMV, Merton) & 0.0276 & 0.7860 & 0.0351 & 0.9721 & \\
Price & -0.0577 & 0.1493 & -0.3862 & 0.7044 & \multirow{2}{*}{ G** } \\
Growth in GDP & -0.0629 & 0.0195 & -3.2320 & 0.0017 & \\
Constant & 0.0391 & 0.0819 & 0.4773 & 0.6343 & \\
\hline R-squared & 0.3575 & & & & \\
Adj. R-squared & 0.3010 & & & & \\
F statistic & 6.3284 & & & & \\
p value (F) & 0.0000 & & & & \\
\hline
\end{tabular}

$\mathrm{DLI}=$ default likelihood indicator, GDP = gross domestic product, $\mathrm{MV}=$ market value, $\mathrm{VAR}=$ value at risk.

*** represents significance at 99 percent.

Source: Authors' calculations.

\section{Conclusion}

The aim of this study was twofold. First, we wanted to examine the evidence for market discipline in a post-reform period. Second, we wanted to provide robust estimation procedures for different risk measures proposed by Basel for risk management. Using a sample of Pakistan's listed commercial banks, we estimated various market-based risk factors to analyze their impact on the cost of deposits.

Our findings support the presence of market discipline, indicated by significant coefficients on our risk factors. Although the sample period was relatively short, this primary evidence supports the argument that the market for bank equity could impose some discipline, and that stock prices reveal relevant information about a bank's risk profile. This is the first study to provide comprehensive estimation procedures for VAR and DLIs, using a dataset for Pakistan. These variables are critical for the internal rating-based approach under the Basel framework, and our empirical contribution can be used to adapt the appropriate risk management tools. 
The presence of market discipline can be beneficial in at least three ways. First, with market discipline in place, banks that indulge in excessive risk-taking activities are likely to pay a higher risk premium to depositors. The increased cost on deposits acts as a penalty for risk-taking banks and moderates their risk-taking behavior. Second, a market discipline mechanism ensures that the cost of bank supervision will be low since government regulation is complemented by market participants. Third, market discipline in the banking sector enhances efficiency by forcing inefficient institutions to become efficient or else exit the system.

It is worth mentioning that the disciplinary feature of capital markets could be increased by making subordinate debt mandatory in order to support regulatory capital. At present, the subordinated debt is used merely to offset the impact of revaluation deficits on Tier-II capital or smaller banks with restricted access to equity markets. Subordinated debts are junior claimants and therefore exposed to the maximum potential loss. Such investors have the greatest motivation to discipline (Pillar 3) banks as compared to depositors (primary claim, contractual guarantees, insurance) and shareholders (limited liability). Based on this argument, many researchers contend in favor of a mandatory subordinated debt policy for commercial banks albeit in developing economies (see Ahmed, 2009; Hamalainen, Howcroft, \& Hall, 2010). This will not only facilitate the development of debt markets in Pakistan, it will also enhance the monitoring function of capital markets, thus curbing the excessive risk appetite of commercial banks and ensuring that the Basel framework is implemented in its true sense. 


\section{References}

Afzal, A., \& Mirza, N. (2010). The determinants of interest rate spreads in Pakistan's commercial banking sector (Working Paper No. 01-10). Lahore, Pakistan: Centre for Research in Economics and Business.

Ahmed, K. (2009). The role of an explicit subordinated debt policy in the smooth transition to Basel II: Developing economy perspective. Journal of Banking Regulation, 10(3), 221-233.

Bank for International Settlements. (2001). Basel II: The New Basel Capital Accord, second consultative paper. Basel, Switzerland: Basel Committee on Banking Supervision.

Black, F., \& Scholes, M. (1973). The pricing of options and corporate liabilities. Journal of Political Economy, 81, 637-659.

Bongini, P., Laeven, L., \& Majnoni, G. (2002). How good is the market at assessing bank fragility? A horse race between different indicators. Journal of Banking and Finance, 26, 1011-1028.

Breen, J., \& Lerner, E. (1973). Corporate financial strategies and market measures of risk and return. Journal of Finance, 28, 339-351.

Bremer, M., \& Pettway, R. (2002). Information and the market's perceptions of Japanese bank risk: Regulation, environment and disclosure. Pacific Basin Finance Journal, 10, 119-139.

Fama, E., \& French, K. (1992). The cross-section of expected stock returns. Journal of Finance, 47, 427-465.

Gropp, R., Vesala, J., \& Vulpes, G. (2006). Equity and bond market signals as leading indicators of bank fragility. Journal of Money, Credit, and Banking, 38, 399-428.

Hamada, S. (1969). Portfolio analysis, market equilibrium and corporation finance. Journal of Finance, 24, 13-31.

Hamalainen, P., Howcroft, B., \& Hall, M. (2010). Should a mandatory subordinated debt policy be introduced in the United Kingdom? Evidence from the issuance activity of banks and building societies. Contemporary Economic Policy, 28(2), 240-263. 
Merton, R. C. (1974). On the pricing of corporate debt: The risk structure of interest rates. Journal of Finance, 29, 449-470.

Mirza, N., \& Afzal, A. (2009). Speculative bubbles in Karachi Stock Exchange (Working Paper No. 02-09). Lahore, Pakistan: Centre for Research in Economics and Business.

Mirza, N., \& Alexandre, H. (2009). Size, value and asset quality premium in European banking stocks [Working paper]. Paris, France: University of Paris Dauphine. Retrieved from http:/ / ssrn.com/abstract $=1411757$

Sharpe, W. (1964). Capital asset prices: A theory of market equilibrium under conditions of risk. Journal of Finance, 19(3), 425-442.

Shimizu, K. (2009). Is the information produced in the stock market useful for depositors? Finance Research Letters, 6, 34-39.

Vassalou, M., \& Xing, Y. (2004). Default risk and equity returns. Journal of Finance, 59(2), 831-868. 